INTERNATIONAL JOURNAL OF RESEARCHES IN BIOSCIENCES, AGRICULTURE AND TECHNOLOGY

(C) VISHWASHANTI MULTIPURPOSE SOCIETY (Global Peace Multipurpose Society) R. No. MH-659/13(N) www.vmsindia.org

\title{
MORTALITY STUDY OF VIVIPARUS BENGALENSIS AFTER EXPOSURE TO THE PHYTOTOXIN FROM AZADIRACHTA INDICA
}

\author{
H. B. Sutar, R. G. Patil, V. R. Jadhav and V. B. Supugade \\ Lal Bahadur Shastri College, Satara. \\ ramraopati121@yahoo.com
}

\begin{abstract}
:
It is common practice to use synthetic chemicals in the control of pesticides but such use of pesticides cause damage to the environment and the living organisms. Hence natural phytotoxins are used in the control of pesticides. The phytotoxin Azadirachta indica is used to study its effect on the biochemical contents of the gills of snail Viviparus bengalensis. The snails were exposed to the phytotoxin from A.indica (neem oil) with sub lethal concentration $148.90 \mathrm{ppm}$ for 24, 48, 72, 96 and $120 \mathrm{hrs}$. to study its effect on the glycogen, proteins and lipids in the gills of the snail $V$. bengalensis. It is observed that glycogen, proteins and lipid contents of gills were reduced. The results were discussed on the basis of metabolism of snails.
\end{abstract}

Keywords:- Azadirachta indica, Viviparus bengalensis, phytotoxin, snails.

\section{Introduction:}

Although synthetic chemicals are more effective they are not trustworthy due their bad effects on the aquatic and sub aquatic animals and their environment. They also destroy the food of organisms such as zooplanktons and phytoplanktons, in addition due to the residual effects of the synthetic chemicals and heavy metals affect the food chain and the water bodies get affected for prolonged period. They may even result in mutation and these changes become prominent after few generations. The chemical pesticides also kill friendly insects. Hence scientists had thought about the alternative way of using plant toxins which are easily degradable, comparatively less expensive and cannot create prolonged hazards in the water. Some of the plant species shows properties like specific toxicity, feeding inhibition, growth regulation, and anti-fertility effects. (Grainge and Ahmed;1985 and Parmer and Devkumar, 1993)

The present work is concerned with study of the one of the important vital activity i.e. respiratory activity of the gastropod, Viviparus bengalensis after its exposure to the phytotoxins from Azadirachta indica. The effect of the phytotoxins on the vital activities of the molluscs is being undertaken for the detailed investigation.

In the present investigation it was decided to carry out detailed analysis of biochemical contents of gills.

\section{Material and Methods:-}

Neem oil from Azadirachta indica used for present study is market product Neem Shastra (having emulsifier itself) was obtained from Siemen's Agrineed Industries 298/295 village Angapur (Vandan), Satara (Maharshtra). $1 \mathrm{ml}$ of Neem Shastra was dissolved in $100 \mathrm{ml}$ 95\% ethyl alcohol; this was a stock solution. This solution further diluted into acetone and desired concentrations were prepared (100 to 500 ppm). The sublethal concentration 148.90 of this oil is used for study of mortality.

\section{Observations:}

Observation on mortality of $V$. bengalensis after its exposure to phytotoxin from $A$. indica.-Fresh water snail, $V$. bengalensis was exposed to the different concentrations such as 100, 200, 300, 400 and $500 \mathrm{ppm}$ of alcoholic extract of $A$. indica (Neem oil) for different time intervals such as 24, 48, 72, 96 and $120 \mathrm{hrs}$. respectively.

The per cent mortality of $V$. bengalensis to the different concentrations of phytotoxin from A. indica was recorded in the Table No. 1 and graphically represented in figure No.1. No mortality was observed in the control set. Motality was initiated in $100 \mathrm{ppm}$ concentration after $48 \mathrm{hrs}$.of exposure period. The maximum mortality was observed after $120 \mathrm{hrs}$. of exposure Azadirachta indica on mortality snail, Viviparus bengalensis

period in each concentration. 15\%, $30 \%, 55 \% 65 \%$ and $80 \%$ mortality was observed respectively in the concentrations 100, 200, 300,400 and 500 ppm respectively after 120 hrs. of exposure period.

Different values such as $\operatorname{LnXY}, \Sigma \mathrm{LnXY}$, LnX, $\Sigma \operatorname{LnX}, \operatorname{LnX}^{2}, \Sigma \operatorname{LnX}^{2}$ were calculated with the help of percentage, mortality, probit $(\mathrm{Y})$ and concentrations in ppm

By using numerical data, the values of ' $b$ ' and ' $a$ ' were calculated. Then the regression 
equations and $\mathrm{LC}_{50}$ were calculated and have been recorded in Table No. 2.

Table. 1:- Per cent mortality of Viviparus bengalensis after exposure to molluscicide Azadirachta indica for different concentrations

\begin{tabular}{|l|l|l|l|l|l|}
\hline \multirow{2}{*}{ Conc. in ppm } & \multicolumn{5}{|c|}{ Per cent mortality } \\
\cline { 2 - 6 } & $\mathbf{2 4}$ hrs & $\mathbf{4 8}$ hrs & $\mathbf{7 2}$ hrs & $\mathbf{9 6}$ hrs & $\mathbf{1 2 0}$ hrs \\
\hline control & 00.00 & 00.00 & 00.00 & 00.00 & 00.00 \\
\hline 100 & 00.00 & 05.00 & 10.00 & 10.00 & 15.00 \\
\hline 200 & 05.00 & 15.00 & 20.00 & 25.00 & 30.00 \\
\hline 300 & 15.00 & 35.00 & 45.00 & 50.00 & 55.00 \\
\hline 400 & 35.00 & 50.00 & 60.00 & 75.00 & 65.00 \\
\hline 500 & 55.00 & 65.00 & 75.00 & 80.00 & 80.00 \\
\hline
\end{tabular}

Table. 2:- Regression equation with LC50 values of Azadirachta indica neem oil on snail, Viviparus bengalensis at different time intervals.

\begin{tabular}{|l|l|l|}
\hline Time of interval (hrs) & Regression equation $(\mathbf{Y = a + b} \mathbf{X})$ & LC50 value in ppm calculated \\
\hline $\mathbf{2 4}$ & $\mathrm{Y}=-10.402+5.8084 \mathrm{X}$ & 446.8 \\
\hline $\mathbf{4 8}$ & $\mathrm{Y}=-2.6503+2.9479 \mathrm{X}$ & 391.8 \\
\hline $\mathbf{7 2}$ & $\mathrm{Y}=-2.1628+2.8577 \mathrm{X}$ & 318.5 \\
\hline $\mathbf{9 6}$ & $\mathrm{Y}=-1.8068+2.8668 \mathrm{X}$ & 275.7 \\
\hline $\mathbf{1 2 0}$ & $\mathrm{Y}=-1.5131+2.6812 \mathrm{X}$ & 263.0 \\
\hline
\end{tabular}

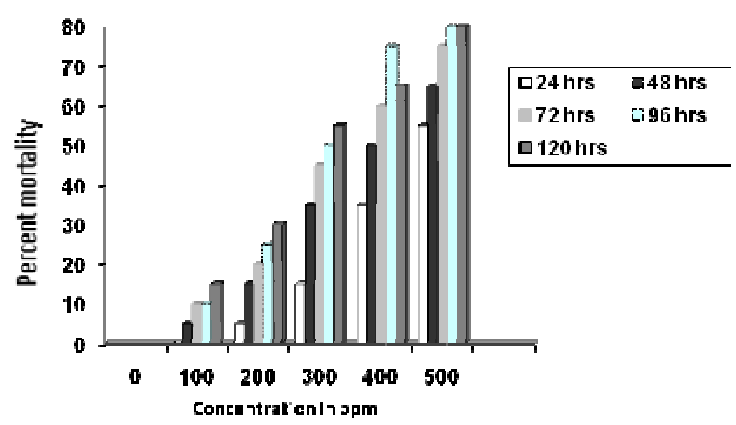

Figure.1 : - Effect of different concentrations of neem oil (Neem Shastra) of

\section{Results and Discussion:}

Mortality is most noticeable effect of pollution and it plays an important role in the toxicological studies. It also helps in the determination of $\mathrm{LC}_{50}$ values of toxicant. In the present study of mortality, different concentrations (100, 200, 300, 400 and $500 \mathrm{ppm}$ ) of the plant toxins from A.indica are used to observe the mortality response in the fresh water snail, V.bengalensis.

It is observed that mortality of V.bengalensis was found altered in different concentrations of phytotxins at different time intervals.

In the present investigation, it is observed that some snails get died earlier to the effect of plant toxins while some try to survive little more time, when all others are dead. This natural variability in mortality responses is due to the resistance power of animal to each concentration. (Mouirhead - Thomson, 1971)

It is also observed that the mortality of snails under study was observed only in intoxicated sets at definite concentrations of the phytotoxins and not in the control set It is true and noticeable that the $\mathrm{pH}$, temperature, salinity, hardness and dissolved oxygen of water in control and experimental set is normal even

after addition of the toxicant. This clearly indicated that no factors other than phytotoxins were responsible in this study for the mortality of snail $V$-bengalensis.

In concentration $100 \mathrm{ppm}$. of the plant toxins from $A$. indica no or less mortality of $V$. bengalensis was observed upto early $24 \mathrm{hrs}$. because of tolerance, mechanism.

Such type of tolerance phenomenon was observed in case of T. mossambicus (Patil, 1988), in $V$. bengalensis from extract of Eupatorium triplinerve (Nanaware et al.; 2003, and Awati, 2004).

The intoxication data on moratality due to pesticides have been reported by many workers. The pesticide intoxication programme was successfully carried out by some workers by activating the high percentage of mortality as reported in Lymnae stagnailis (Bhide 1986 and 1989), in Pila globosa (Bhide 1987), Antheraea agsama (Bora and Handique 1990), in Indonaia caeruceus (Muley 1989) and in Lymnaea stagnalis (Bhide 1991). 
Percent mortality data recorded in Table No. 1 indicated that the rate of mortality is less in lower concentrations while it is more in higher concentrations of phytotoxins. The per cent mortality in the Experimental snails was also seen increased with increase in the exposure period. Therefore per cent mortality in the snails under study was found associated with the concentration of toxicant and intoxication period. This also suggests that the rate of mortality in snail, $V$. bengalensis is increased with increase in the concentration of the plant toxins $A$. indica and with increase in the intoxication period also.

Lokhande and Kulkarni (1990) have reported the effect of pesticide toxicity in combination with temperature and $\mathrm{pH}$ in Bellamya bengalensis, with similar observations.

According to Malu and Kulkarni (1990) increased mortality is due to increased endosulfan and malthion residue with respect to pesticide exposure time. Higher accumulation of pesticides in mantle than foot and hepatopancreas showed increased mortality in the snail, Viviparus bengalensis by (1990) and it was more probably due to pesticide residue accumulation in Lmnaea stagnalis as reported by Bhide, 1986 and 1989 Similar observations were recorded by Bhide (1987) in Pila globosa.

The present investigation provides the data derived form dose concentration and percent mortality for the determination of $\mathrm{LC}_{50}$ values and regression equation by probit analysis. The $\mathrm{LC}_{50}$ values of plant toxins for snail $V$. bengalensis were calculated with respect to the plant toxins derived from $A$. indica. The regression equation is useful for the calculation of lethal concentration. The calculated $\mathrm{LC}_{50}$ value of phytotoxin A.indica to the snail $V$. Bengalensis is $263.0 \mathrm{ppm}$.

\section{Acknowledgements:-}

We are very much thankful to the Prin. Abhaykumar Salunkhe, Karyadhyaksh, Shri Swami Vivekanand Shikshan Sanstha, Kolhapur and Prin. Dr. R. V. Shejwal, Lal Bahadur Shastri College, Satara for providing necessary laboratory facilities.

\section{References:-}

1. Awati A. A.(2004);Comparative study on toxic effect of synthetic and natural molluscicides on respiratory and reproductory physiology of aquatic snail, Viviparus bengalensis (Larmarck), Ph. D. thesis submitted in Zoology to Shivaji University, Kolhapur.
2. Bhide M. (1986) : Effects of thioures on the development of Lymnea stagnalis. Symp. On Man. Bioresources Development and Environ. Ab.No. 46, 42.

3. Bhide M. (1987) :Toxicity of certain pesticides on the behaviour, mortality and on the development of the fresh water snail, Pila globasa and their egg masses. Trends in Environ. Pollu. And Pesticides Toxicology, Jagminder Book Agency, New Delhi, 355362.

4. Bhide M. (1989) : Comparative Studies on the effect of thiorea BHC on behaviour and mortality in adult snails of the species Lymnea stagnalis, and on their egg masses Folia Morphologica. 37(1) 13-18.

5. Bhide M. (1991) : Effect of organophosphorus perticides on the behaviour, mortality and on the development of Lymnea stagnalis, In : Perspective in Aquatic Eco. Toxico. (Ed: Nalim K. Shastree), Narandra Publishing House Delhi, 110005, India.

6. Grainage, M. and Ahmed, S.(1985) Handbook of plants with pest control properties 470-502.

7. Lokhande P.L. and Kulkarni K.M. (1990) ; Interaction of environmental parameters with toxicity of fresh water snail B.bengalensis. Ann.Sess Acad.Env.Bio. Aurangabad symp 13-23.

8. Malu R.A. and Kulkarni : (1990) Accumulation of pesticides in the snail Bellamya bengalensis exposed at different time intervals. II Ann Sess. Acad. Environ. Biol. Aurangabad Symp 17-25.

9. Muley D.V. and Mane U.H.(1989); Mercurial salt induced changes in respiration of fresh water gastropod, V.bengalensis. Poll. Res. Vol. 8, 141-144.

10. Muirhead-Thomson, R.C. (1971) : In : Pesticides and fresh-water Fauna, Academic Press London and New York, PP 71-90.

11. Nanaware S.G. , Deshmane Jini and Jadhav V.R. (2003); Studies on natural molluscicides induced changes in the nutrients of gills of snail, Bellamya bengalensis. Proc. Biology and Biotech Abst. 51.

12. Parmer B.S. and Devkumar C. (1993) Botanical and Biophesticides SPS publication No. 4 Society of Pesticides Science : India Westwill Publishing house, New Delhi PP 73. 